Henryk Dzwonkowski

\title{
Ocena skutków regulacji zawartych w poselskim projekcie ustawy Karta Praw Podatnika'
}

\author{
Impact assessment of regulations contained in the Deputies' Bill \\ on the Taxpayers' Rights Charter
}

\begin{abstract}
In the opinion of the author, the draft provisions duplicate the existing regulations in the field of taxpayer's rights arising from the Constitution of the Republic of Poland and the Tax Ordinance. However, the implementation of the goal assumed by sponsors of the bill is desirable and would certainly meet with a positive public perception. The author emphasizes that an alternative solution could be the development of an act constituting an exhaustive set of taxpayers' rights and the corresponding obligations of tax authorities, on a legal basis arising from the Constitution or laws.
\end{abstract}

Keywords: constitution, taxpayer, bill

Zdaniem autora opinii projektowane przepisy stanowią powielenie dotychczas obowiązujących regulacji w zakresie praw podatnika, wynikających z Konstytucji RP oraz ustawy o ordynacji podatkowej. Jednak realizacja celu zakładanego przez projektodawcę jest pożądana i z pewnością spotkałaby się z pozytywnym odbiorem społecznym. Autor podkreśla, że alternatywnym rozwiązaniem mogłoby być opracowanie aktu stanowiącego wyczerpujący zbiór praw podatników oraz odpowiadających im obowiązków organów podatkowych, na podstawie prawnej wynikającej z Konstytucji lub ustaw.

Słowa kluczowe: konstytucja, podatnik, projekt ustawy

Doktor hab. nauk prawnych, profesor UŁ •

Uniwersytet Łódzki, Wydział Prawa i Administracji, ŁÓDŹ, POLSKA •

hdzwonkowski@poltax.pl • https://orcid.org/0000000271103029

\section{Zakres przedmiotowy ustawy}

Projekt przewiduje wprowadzenie do polskiego porządku prawnego nowej instytucji, jaką jest Karta Praw Podatnika (dalej: Karta). Projekt tożsamej treści był również zgłaszany w poprzedniej kadencji Sejmu, jednakże nie został uchwalony przed jej zakończeniem (zob. druk nr 3458/VIII kad.).

Proponowana Karta Praw Podatnika określa w sposób zwięzły, choć nie do końca precyzyjny (co zostanie opisane w dalszej części opinii) podstawowe prawa podatników, a także stanowiące ich korelat - obowiązki organów podatkowych.

$1 \quad$ Ocena skutków regulacji zawartych $w$ poselskim projekcie ustawy Karta Praw Podatnika (druk nr 137) sporządzona 9 stycznia 2020 r. na zlecenie zastępcy Szefa Kancelarii Sejmu; BAS 248/19. 
Innymi słowy, Karta stanowić ma ujęte w jednym akcie prawnym kompendium wiedzy na temat praw przysługujących podatnikowi i odpowiadających im obowiązkach organów podatkowych. Przy czym zakresem podmiotowym obejmuje również inne podmioty, których prawa i obowiązki są regulowane przepisami prawa podatkowego, zwłaszcza płatników, inkasentów, osoby trzecie odpowiedzialne za zaległości podatkowe oraz następców prawnych.

Projekt dotyczy przede wszystkim sektora finansów publicznych oraz spraw społecznych.

\section{Podmioty, na które oddziałuje akt}

Projekt dotyczy takich podmiotów, jak: podatnicy, a także inne podmioty, których prawa i obowiązki są regulowane przepisami prawa podatkowego, w tym: płatników, inkasentów, osób trzecich odpowiedzialnych za zaległości podatkowe, następców prawnych, a także pełnomocników tych podmiotów (tj. doradców podatkowych, adwokatów, radców prawnych), oraz organów administracji podatkowej (także samorządowych organów podatkowych), sądów administracyjnych, Rzecznika Praw Obywatelskich, ministra właściwego do spraw finansów publicznych, organów stanowiących jednostek samorządu terytorialnego.

\section{Celowość wprowadzenia aktu}

Cele projektu zostały określone w jego preambule. Wedle jej treści ma on realizować dwa zasadnicze założenia. Po pierwsze, zapewnić należytą ochronę praw podatników przez odpowiednie wyważenie interesu publicznego i prywatnego w prawie podatkowym. Po drugie, projekt ma służyć zwiększaniu świadomości społecznej co do istnienia i zakresu praw podatnika.

W ocenie autorów projektu dotychczasowy brak w polskim porządku prawnym Karty Praw Podatnika stanowi przejaw nienadążania za najlepszymi praktykami światowymi. Konieczność przyjęcia Karty motywowana jest również tym, że zmiany w prawie podatkowym, niekiedy godzące $\mathrm{w}$ prawa podatnika oraz spotykane naruszenia praw podatnika w procesie stosowania prawa, skutkują potrzebą wprowadzenia Karty jako nowego instrumentu wzmacniającego ochronę tych praw, zarówno na etapie tworzenia, jak i stosowania prawa podatkowego. Projekt ma ponadto łagodzić skutki istniejącej nierównowagi między pozycją podatnika oraz organu podatkowego (będącego gospodarzem postępowania podatkowego), a także zwiększać zaufanie podatnika do państwa.

$\mathrm{W}$ istocie Karta ma do odegrania rolę porządkującą, wzmacniającą oraz edukacyjną. W swej krótkiej formie ma za zadanie ułatwić podatnikom, zwłaszcza tym niekorzystającym z usług profesjonalnych pełnomocników, odnalezienie 
i powołanie konkretnej podstawy prawnej właściwej dla ochrony ich praw. Regulacje wynikające z projektu mają za zadanie wzmocnić ochronę praw podatnika poprzez ich usystematyzowanie $\mathrm{w}$ formie zasad prawa podatkowego. Założeniem jest, by normy zapisane w Karcie były stosowane łącznie z innymi normami albo bezpośrednio i samodzielnie. Pełnić mają zatem funkcję urzeczywistniającą oraz poszerzającą zakres ochrony praw zagwarantowanych w obszarze prawa podatkowego.

Regulacja nie stanowi efektu zaleceń Unii Europejskiej. Na gruncie międzynarodowym podejmowano próby sformułowania uniwersalnych katalogów praw podatnika, jednakże nie mają one charakteru wiążącego. Cel ustawy jest konkretny, natomiast trudno mierzalny.

\section{Planowane środki (narzędzia i działania) realizacji celów}

Projektodawcy proponują wprowadzenie Karty Praw Podatnika w formie odrębnego dokumentu, mającego charakter normatywny (ustawa). Argumentując konieczność przyjęcia projektu w formie ustawy, wskazano, że siła oddziaływania na praktykę stosowania prawa podatkowego będzie istotnie wyższa niż w przypadku przyjęcia innego dokumentu o charakterze deklaratoryjnym wydanym przez organy administracji podatkowej. Jako świadczący o tym przykład podano opublikowaną przez Ministerstwo Finansów w 2018 r. informację Uprawnienia i obowiązki podatników $w^{2}$, stanowiącą swoisty zbiór praw podatnika, która - ze względu na swój niewiążący charakter - ma marginalne znaczenie dla praktyki stosowania prawa podatkowego i niemalże nie funkcjonuje $\mathrm{w}$ świadomości podatników. Dlatego też, w ocenie projektodawcy, najlepszym rozwiązaniem ma być przyjęcie formy ustawy, ale znacznie krótszej i napisanej prostszym językiem niż inne akty prawne $\mathrm{z}$ zakresu prawa podatkowego, tj. bardziej przystępnym i zrozumiałym dla przeciętnego podatnika.

Zwiększaniu świadomości i popularyzacji Karty Praw Podatnika sprzyjać ma również wynikający z art. 2 ust 2 projektu obowiązek doręczenia każdemu podatnikowi (a także innemu podmiotowi, którego prawa i obowiązki są regulowane przepisami prawa podatkowego) egzemplarza Karty przy wszczęciu postępowania podatkowego, kontroli podatkowej oraz kontroli celno-skarbowej, jak również jej publikacja na stronach internetowych organów podatkowych.

Proponuje się również przyjęcie mechanizmów, które mają pozwolić na monitorowanie zakresu naruszeń praw podatników przez organy podatkowe oraz przekazywania tych informacji właściwym instytucjom i organom (również tym, które bezpośrednio odpowiedzialne są za jakość stanowionego prawa podatkowego).

2 Https://www.podatki.gov.pl/abc-podatkow/uprawnienia-i-obowiazki-podatnika/ [dostęp 8 stycznia 2020 r.] 
Alternatywą dla proponowanego rozwiązania są obowiązujące dzisiaj regulacje normujące prawa podatnika i odpowiadające im obowiązki organów podatkowych, które mają charakter bardziej rozproszony, ponieważ wynikają tak z Konstytucji, jak i ustawy - Ordynacja podatkowa. Alternatywę zaś dla zaproponowanej ustawowej formy omawianej Karty mógłby stanowić dokument o charakterze deklaratoryjnym, który przybrałby postać np. broszury informacyjnej czy deklaracji, w treści której określone i opisane byłyby prawa podatników oraz odpowiadające im obowiązki organów podatkowych wraz z powołaniem właściwej podstawy prawnej znajdującej się w obowiązujących przepisach Konstytucji oraz Ordynacji podatkowej. Broszura - podobnie jak w proponowanym w projekcie rozwiązaniu - mogłaby być przesyłana na etapie wszczęcia postępowania podatkowego, kontroli podatkowej czy kontroli celno-skarbowej podatnikowi (oraz innym podmiotom wymienionym w projekcie), co przyczyniałoby się w sposób bezpośredni do poszerzenia świadomości podatników co do przysługujących im praw oraz do realizacji celów projektu. Takie rozwiązanie wymagałoby również nowelizacji ustawy - Ordynacja podatkowa w zakresie, w jakim projekt co do niektórych wymienionych w Karcie praw przewiduje bardziej korzystne niż dotychczasowe rozwiązania. Kolejno, wysoce pożądanym rozwiązaniem (w miejsce mnożenia regulacji prawnych) mogłoby być także położenie zdecydowanego nacisku na kształcenie i edukowanie pracowników aparatu skarbowego odpowiedzialnych bezpośrednio za stosowanie przepisów prawa podatkowego, mające na celu podniesienie kultury administrowania, jak również prowadzenie kampanii informacyjnych w celu zwiększenia świadomości prawnej podatników, co do przysługujących im praw i obowiązków ciążących na właściwych organach.

\section{Ocena kosztów i korzyści}

\section{Skutki prawne}

Pozytywnie należy ocenić projektowane rozszerzenie zakresu podmiotowego ochrony praw podatników także na innych uczestników postępowania podatkowego, w tym płatników, inkasentów, osoby trzecie odpowiedzialne za zaległości podatkowe oraz następców prawnych.

Pewne wątpliwości może budzić jednakże przyjęta przez projektodawcę forma ustanowienia Karty Praw Podatnika w drodze ustawy, a to z uwagi na obowiązujące $\mathrm{w}$ zakresie zasad techniki prawodawczej postanowienia rozporządzenia Prezesa Rady Ministrów z 20 czerwca 2002 r. w sprawie „Zasad techniki prawodawczej” (t.j. Dz.U. 2016, poz. 283; dalej: rozporządzenie). Stosownie do postanowień $₫ 4$ ust. 1 przywołanego rozporządzenia: ustawa nie może powtarzać przepisów zamieszczonych w innych ustawach. Tymczasem zaproponowana przez projektodawcę Karta w części (zwłaszcza w zakresie, w jakim stanowi właśnie o prawach podatników i odpowiadających im obowiązkach organów podatko- 
wych), stanowi odzwierciedlenie obowiązujących na dziś w tej materii regulacji prawnych, zamieszczonych przede wszystkim w ustawie - Ordynacja podatkowa. Przykładowo wskazać można, że:

- obowiązujący art. $121 \$ 1$ Ordynacji podatkowej stanowi, że: Postępowanie podatkowe powinno być prowadzone w sposób budzacy zaufanie do organów podatkowych, zaś odpowiadający jego treści art. 13 ust. 2 projektu ma przyjąć brzmienie: Organy podatkowe i sady rozstrzygając sprawę podatkowa maja obowiązek działać w sposób budzący zaufanie, kierując się zasadami bezstronności i równego traktowania,

- obowiązujący art. $125 \$ 1$ Ordynacji podatkowej stanowi, że: Organy podatkowe powinny działać w sprawie wnikliwie i szybko, postugując się możliwie najprostszymi środkami prowadzacymi do jej załatwienia, zaś odpowiadający jego treści art. 14 ust. 1 projektu ma otrzymać brzmienie: Organy podatkowe mają obowiązek działać w sprawie wnikliwie i szybko, dążac do ograniczenia kosztów własnych i kosztów podatnika,

- obowiązujący art. 2a Ordynacji podatkowej stanowi, że: Niedajace się usunąć wątpliwości co do treści przepisów prawa podatkowego rozstrzyga się na korzyść podatnika, zaś odpowiadający mu art. 6 ust. 4 projektu ma otrzymać brzmienie: Niedające się usunać wątpliwości co do treści normy prawa podatkowego rozstrzyga się na korzyść podatnika.

$\mathrm{Z}$ uzasadnienia projektu można wywnioskować, że takie działanie było zabiegiem celowym, ponieważ: podstawowym zadaniem proponowanej karty nie jest przyznanie podatnikom nowych praw, bo te wynikaja już z Konstytucji, a także $z$ ustaw szczegółowych prawa proceduralnego i materialnego. Karta ma zadanie wzmocnić ochronę tych praw, poprzez usystematyzowanie ich $w$ formie zasad systemu prawa podatkowego (uzasadnienie projektu, s. 11). Normy przyjęte przez projektodawcę, jako wyrażone w prawie pozytywnym, mają cechować się szczególną doniosłością dla systemu prawa podatkowego jako całości, poszczególnych jego części i instytucji. Projektodawca, argumentując o konieczności przyjęcia Karty w formie ustawy, wskazał, że: siła oddziaływania na praktykę stosowania prawa podatkowego karty o charakterze normatywnym będzie z pewnościa większa, niż gdyby poprzestać na dokumencie deklaratywnym pochodzacym od administracji podatkowej (uzasadnienie projektu, s. 9). Należy jednak zauważyć, że powielanie treści niektórych przepisów Ordynacji podatkowej może paradoksalnie nastręczać trudności także samym podatnikom oraz ich pełnomocnikom, w tym sensie, że $\mathrm{w}$ trakcie sporu $\mathrm{z}$ organem podatkowym konieczne będzie powołanie się na treść obu przepisów prawnych, tj. wynikających z ustawy - Ordynacja podatkowa oraz pomocniczo - opiniowanej ustawy, często o analogicznej treści (okoliczność ta nabierze szczególnego znaczenia zwłaszcza na etapie składania skargi kasacyjnej). Dodatkowym utrudnieniem może być również okoliczność, że w opiniowanym brzmieniu Karty część jej postanowień w sposób nie do koń- 
ca precyzyjny odzwierciedla treść przepisów ustawy, co może utwierdzić podatnika w przekonaniu o istnieniu normy prawnej bardziej korzystnej dla niego niż wynikająca z przepisów obowiązującego prawa. Powyższe obrazuje np. treść art. 21 Karty, w świetle której wniesienie środka zaskarżenia nie może pogarszać sytuacji podatnika w postępowaniu administracyjnym i sądowym w sprawach podatkowych, podczas gdy art. 234 Ordynacji podatkowej przewiduje wyjątki od zasady zakazu reformationis in peius. W konsekwencji, w razie uchwalenia Karty, w obrocie prawnym zaistniałyby dwa niezgodne ze sobą przepisy rangi ustawowej. W związku z powyższym w Karcie powinny zostać poczynione stosowne zastrzeżenia, aby podatnik był świadom, że dla ustalenia zakresu swoich praw winien dokonać wykładni przepisów Karty oraz ustawy - Ordynacja podatkowa.

Ponadto nie ma wątpliwości, że uchwalenie Karty w formie ustawowej sprzyjać będzie wzrostowi świadomości podatników co do przysługujących im praw, natomiast w żadnej mierze nie zagwarantuje wzrostu kultury administrowania przez organy podatkowe. W tej materii: z uwagi na charakter tych praw właściwa płaszczyzna ich ochrony jest sfera pozaprawna, gdzie należy podejmować działania w zakresie wzrostu świadomości i kultury prawnej wśród pracowników aparatu skarbowego i podatników $w^{3}$. Tym samym, zapewnienie poszanowania praw podatników i obowiązków ciążących na organach podatkowych możliwe byłoby dzięki prowadzeniu działań szkoleniowych i edukacyjnych wśród podmiotów bezpośrednio odpowiedzialnych za stosowanie prawa podatkowego bądź realizację zaproponowanego wyżej alternatywnego rozwiązania. Wydaje się bowiem, że problemem nie jest brak normatywnego katalogu praw podatników (te wynikają już bowiem z ustawy oraz Konstytucji RP), ale brak świadomości podatników oraz stosowanie prawa przez organy podatkowe w sposób prowadzący niejednokrotnie do ich naruszenia.

W odniesieniu do powyższych wątpliwości należy wskazać jednak, że, po pierwsze, Karta w projektowanym kształcie nie stanowi jedynie powielenia treści niektórych przepisów Ordynacji podatkowej (a tym samym praw przysługujących podatnikom), ale spełnia również inne zadania, które projektodawca przed nią postawił. Przede wszystkim w przyjętej formie prowadzi do usystematyzowania praw podatników oraz obowiązków organów podatkowych i powoduje, że stają się one bardziej czytelne i dostępne dla stron postępowania podatkowego. Ponadto projektowane przepisy uszczegóławiają dotychczasowe przepisy, a niekiedy także rozszerzają ich zakres, co pozytywnie wpływa na wzmocnienie pozycji podatnika jako słabszej strony postępowania (zob. art. 9 ust. 3 projektu, który stanowi, że na korzyść podatnika należy rozstrzygać także niedające usunąć się wątpliwości co do stanu faktycznego).

3 H. Dzwonkowski, M. Duda, J. Gorąca, Zakres i treść istniejącej i pożądanej ochrony praw podatnika (ustalenia de lege lata i postulaty de lege ferenda) [w:] Dylematy reformy systemu podatkowego w Polsce, red. H. Dzwonkowski, J. Kulicki, Warszawa 2016, s. 308. 
Po drugie zaś, należy zwrócić uwagę na charakter przywołanych wcześniej zasad techniki prawodawczej. W orzecznictwie Trybunału Konstytucyjnego wskazuje się, że istota znaczenia zasad techniki prawodawczej sprowadza się do tego, iż stanowią one: prakseologiczny kanon, który powinien być respektowany przez ustawodawce demokratycznego państwa prawnego $0^{4}$. Jak trafnie wskazuje się w literaturze przedmiotu, mimo że zasady te są w Polsce zawarte w akcie normatywnym, to nie stanowią klasycznych dyrektyw o charakterze normatywnym, ale raczej zbiór wytycznych, czyli reguł wskazujących, jak poprawnie konstruować akty normatywne ${ }^{5}$. Nie przewidziano bowiem za ich naruszenie jakichkolwiek sankcji. Innymi słowy, odstępstwo od przewidzianych w przywołanym rozporządzeniu zasad uzasadnione może być brakiem ich wiążącego charakteru i jako takie - nie sprzeciwia się w sposób bezwzględny uchwaleniu omawianego projektu $\mathrm{w}$ proponowanych kształcie, choć stanowi ich naruszenie skutkujące istotnym obniżeniem poziomu legislacji.

Powyższe oznacza, że mimo wątpliwości, jakie mogą powstać co do zgodności projektu z rozporządzeniem regulującym zasady techniki prawodawczej, pozytywnie należy ocenić cel, jaki mu przyświeca. Istotnym założeniem jest bowiem, by Karta stanowiła swoiste kompendium wiedzy na temat praw podatnika i odpowiadających im obowiązków organów podatkowych oraz by przyczyniała się do wzrostu świadomości prawnej podatników oraz innych wskazanych w projekcie podmiotów, nie wprowadzając ich jednocześnie w błąd co do obowiązującego stanu prawnego.

W odniesieniu zaś do projektowanego art. 27 należy wskazać, że przewiduje on obowiązek przekazywania przez samorządowe organy podatkowe corocznych sprawozdań o przestrzeganiu praw podatnika na rzecz organów stanowiących jednostek samorządu terytorialnego, jednak $\mathrm{z}$ omawianego projektu nie wynika jakoby informacje te - poza ich gromadzeniem - miały jakiekolwiek potencjalne możliwości wywarcia wpływu na proces legislacyjny i ewentualne zmiany w prawie. W projekcie nie uregulowano bowiem dalszych losów tych sprawozdań, poza wskazaniem, że są one przekazywane organowi stanowiącemu jednostki samorządu terytorialnego i przez niego gromadzone.

\section{Skutki społeczne}

Projekt $\mathrm{z}$ dużym prawdopodobieństwem spotka się z pozytywnym odbiorem społecznym, może wpłynąć na zwiększenie świadomości podatników (oraz innych uczestników postępowania podatkowego) co do przysługujących im w toku tego postępowania praw, a ponadto może w sposób pozytywny wpływać na wzrost zaufania podatników do działań organów podatkowych.

4 Zob. wyrok TK z 21 marca 2001 r., sygn. akt K 24/00, OTK ZU 2001, nr 3, poz. 51.

5 S. Wronkowska, O meandrach skuteczności nowych zasad techniki prawodawczej, „Przegląd Legislacyjny” 2004, nr 4, s. 11. 
Biorąc pod uwagę polskie doświadczenia, świadomość prawną polskich podatników oraz stan polskiego prawa podatkowego, zdefiniowanie omawianego katalogu praw podatników w postaci Karty ma swoje uzasadnienie i zostanie w sposób przychylny przyjęty przez społeczeństwo. Jednakże w przypadku rozbieżności pomiędzy treścią przepisów ustawy - Ordynacja podatkowa (na co wskazano również przy opisie „Skutków prawnych” projektu) a treścią Karty mogą jednak wprowadzać podatnika w błąd, co może skutkować obniżeniem poziomu zaufania podatnika do państwa i stanowionego przezeń prawa.

\section{Skutki administracyjno-organizacyjne}

Projekt może wpłynąć na zwiększenie liczby obowiązków ciążących między innymi na:

- sądach administracyjnych - w zakresie, w jakim przewiduje on obowiązek informowania ministra właściwego do spraw finansów publicznych o każdym dostrzeżonym rażącym naruszeniu praw podatnika przez organy podatkowe (art. 25 projektu),

- ministrze właściwym do spraw finansów publicznych - w zakresie, w jakim przewiduje on obowiązek gromadzenia oraz analizy informacji przekazywanych przez sądy administracyjne (art. 25 projektu) i pełnomocników (z art. 17 ust. 3 projektu) oraz składania Sejmowi corocznego sprawozdania o przestrzeganiu praw podatnika,

- Rzeczniku Praw Obywatelskich - w zakresie, w jakim przewiduje on obowiązek gromadzenia oraz analizy danych przekazywanych przez pełnomocników dotyczących rażącego naruszenia praw podatników (art. 17 ust. 3 projektu) oraz możliwość realizacji uprawnień przewidzianych w art. 28 projektu, zakładających m.in. możliwość formułowania ocen, wniosków i rekomendacji, a także żądania wyjaśnień od organów podatkowych,

- samorządowych organach podatkowych - w zakresie, w jakim przewiduje on obowiązek składania organowi stanowiącemu jednostki samorządu terytorialnego sprawozdania o przestrzeganiu praw podatnika,

- organach stanowiących jednostek samorządu terytorialnego - w zakresie, w jakim przewiduje on obowiązek gromadzenia sprawozdań o przestrzeganiu praw podatnika,

- organach administracji podatkowej - w zakresie, w jakim przewiduje on obowiązek przesyłania podatnikom (i innym podmiotom wymienionym w projekcie) egzemplarza Karty przy wszczęciu postępowania podatkowego, kontroli podatkowej oraz kontroli celno-skarbowej.

Powyższe oznacza, że realizacja wskazanych obowiązków może wiązać się dla tych podmiotów z koniecznością reorganizacji pracy dotychczas zatrudnianych pracowników lub - w zależności od liczby i zakresu dostrzeżonych rażących naruszeń praw podatników - w ostateczności także z koniecznością zatrudnienia 
dodatkowego pracownika do obsługi zadań wynikających z projektu bądź pokrycia kosztów związanych np. ze zleceniem podmiotowi zewnętrznemu opracowania sprawozdania o przestrzeganiu praw podatnika.

\section{Skutki finansowe}

W opiniowanym projekcie zaproponowano, by w celu wzrostu świadomości podatników (i innych wymienionych tam podmiotów) co do przysługujących im praw zobligować organy podatkowe, by każdorazowo na etapie wszczęcia postępowania podatkowego, kontroli podatkowej oraz kontroli celno-skarbowej przesyłały im egzemplarz Karty. Projektodawca nie wskazał jednak, jakie koszty dla budżetu państwa może pociągnąć takie rozwiązanie, niemniej można oczekiwać, że nie będą one stanowily istotnego obciążenia dla budżetu państwa.

Można również spodziewać się, że pewne obciążenia po stronie budżetowej mogłyby również (o ile w praktyce będzie to konieczne - co jest na obecnym etapie trudne do przewidzenia i zależne od ilości zgłaszanych w przyszłości naruszeń praw podatników) wiązać się z koniecznością zatrudnienia dodatkowych pracowników, w celu zagwarantowania realizacji zadań wynikających z przyjęcia projektu.

\section{Podsumowanie - ogólna ocena projektu}

W obliczu stosunkowo niskiej kultury administrowania przez organy podatkowe odpowiedzialne za przestrzeganie i poszanowanie praw podatników zasadne jest podejmowanie wszelkich kroków zmierzających do, po pierwsze, zwiększenia świadomości podatników co do przysługujących im praw, po drugie zaś, do wzrostu tej kultury u podmiotów stosujących prawo. Wątpliwości budzi natomiast proponowana przez projektodawców forma Karty (forma ustawowa) $\mathrm{z}$ uwagi na zastrzeżenia poczynione w opisie skutków prawnych projektu. Warto zatem rozważyć alternatywne rozwiązania w postaci np. przyjęcia aktu o charakterze deklaratoryjnym, stanowiącym zbiór praw podatników i odpowiadających im uprawnień organów podatkowych (wraz z podaniem odpowiedniej podstawy prawnej), który - tak jak w proponowanym rozwiązaniu byłby przesyłany do podatnika (i innych podmiotów) każdorazowo na etapie wszczęcia postępowania podatkowego, kontroli podatkowej lub kontroli celno-skarbowej, oraz dokonanie odpowiedniej nowelizacji ustawy - Ordynacja podatkowa. Ostatecznie należy również ocenić, że realizacja celu zakładanego przez projektodawcę jest wysoce pożądana. Z pewnością spotkałaby się z pozytywnym odbiorem społecznym i mogła w sposób bezpośredni przyczynić się do wzrostu zaufania podatników do organów stosujących prawo podatkowe. 


\section{Bibliografia}

Dzwonkowski H., Duda M., Gorąca J., Zakres i treść istniejącej i pożądanej ochrony praw podatnika (ustalenia de lege lata i postulaty de lege ferenda) [w:] Dylematy reformy systemu podatkowego w Polsce, red. H. Dzwonkowski, J. Kulicki, Warszawa 2016.

Wronkowska S., O meandrach skuteczności nowych zasad techniki prawodawczej, „Przegląd Legislacyjny" 2004, nr 4. 